\title{
Improving Reading Comprehension of First Year Engineering Students: A Quantitative Study at QUEST, Nawabshah, Pakistan
}

\author{
Mansoor Ahmed Channa ${ }^{1}$, Zaimuariffudin Shukri Nordin ${ }^{2} \&$ Abdul Malik Abassi ${ }^{3}$ \\ ${ }^{1}$ Quaid-e-Awam University of Engineering, Science, and Technology, Nawabshah, Pakistan \\ ${ }^{2}$ Faculty of Cognitive Sciences \& Human Development, University Malaysia Sarawak, Malaysia \\ ${ }^{3}$ Sindh Madressatul Islam University, Karachi, Pakistan \\ Correspondence: Mansoor Ahmed Channa, Quaid-e-Awam University of Engineering, Science, and Technology, \\ Nawabshah, Pakistan. E-mail: mansoor.english@yahoo.com
}

\author{
Received: October 18, 2017 Accepted: December 2, 2017 Online Published: February 4, 2018 \\ doi:10.5539/ijel.v8n3p47 URL: http://doi.org/10.5539/ijel.v8n3p47
}

\begin{abstract}
This paper reports the results of the research conducted to explore whether students learn reading comprehension more successfully using the different approaches based on strategies in reading texts. The study was conducted at QUEST, in Pakistan and the respondents were selected from four engineering departments. Data was collected through a set of questionnaire used as the qualitative instrument among 311 respondents. However, Questionnaire data was analyzed by using SPSS 17. Descriptive statistics were used to analyze research variables for producing the Percentages, Mean and Standard Deviation of the data. The findings of this study reported that this research investigated 18 categories of reading comprehension. The highest mean score in reading comprehension was for "read aloud practices" category $(=2.40)$ rated by all respondents; while the mean score for "asking questions before, during, and after reading" (=1.48) was the lowest. However, no category of reading comprehension fell into low level of usage. In short, results, discussion and recommendations are presented for developing effective reading strategies to design syllabus for the engineering students to improve their reading proficiency.
\end{abstract}

Keywords: strategies, reading comprehension, reading barriers

\section{Introduction}

It is annoying for engineering students when they are unable to understand what they read and what they comprehend. Most engineering students when struggle for the comprehension of text; they over and over again lose their aspiration to prolong reading. Further, reading comprehension is indispensable to ensure engineering students' literacy for understanding as well as retaining the information they learnt through reading various text books. However, comprehension is a fundamental piece of learning how to read; it can be regarded as a multifaceted procedure based on different levels. It is imperative for teachers to know how the engineering students interact with text so that they can fathom out certain strategies as the most beneficial for developing reading comprehension abilities. Further, previously, there were no specific studies aimed at the barriers to reading comprehension as experienced by engineering students. Moreover, the main issues of engineering students were based on low, average, and high reading proficiency levels of students. Their inability to read is affected due to the factors that include intellectual, psychological, physical, socio-economic, gender difference, urban and rural area, age, government and private schooling background, learning environment, and teaching methodology. In addition, students' reading knowledge is also varied due to their learning competency, their behaviors due to urban and rural areas and motivations in reading engineering subjects. Thus, they felt difficulties in handling and comprehending the texts and materials. The teachers are responsible to develop lessons plans based on certain tasks of reading and activities for comprehension to encompass the learning of readers through metacognitive strategies of reading comprehension. In short, the main issues of engineering students in terms of reading text are based on reading barriers or difficulties, high or low reading levels, the way of reading and comprehending, word-by-word reading, poor pronunciation, omissions, repetitions, poor word attack skills, inadequate vocabulary, low reading speed, inability to locate information and inadequate comprehension. This study would be the great contribution because this area was not investigated in the past in Pakistan. This also would be different in the field by addressing the concerns of engineering students in Pakistani Universities to examine the gains in teachers scaffolding and 
metacognitive strategies through reading comprehension.

This research was aimed to investigate metacognitive strategies used by engineering students and teachers from engineering departments to promote reading comprehension in Pakistan. There are different reading theories and models that offered help to develop comprehension. The cognitive theories in terms of reading and comprehension focused on different approaches. Reading comprehension needed readers to understand the text which they read. Cohen (1998) asserted that metacognitive strategies partially played a part as the operational strategies to boost up students' reading ability. Similarly, Hammadou (1991) stated that students want to upgrade their reading comprehension ability by means of incorporating their former awareness, reading ability, and metacognitive strategies through comprehension of words and sentences in a text to be capable to read efficiently and perceptively. Cohen (1998) further, asserted that metacognitive strategies in reading comprehension help students to make planning before they read, to control monitoring in the reading process, and to make evaluation in terms of their reading and comprehending in the end of the text. Moreover, Anderson (1991) informed that these readers interlink the key facts of the reading with their prior knowledge. Flemming (1997) informed that synthesizing the reading text is very important reading process in which readers assign their own words for forming meaningful concept. Leddy (2008) wrote that public attention was focused on the reading abilities (or disabilities) of students. Similarly, Levitov (2010) reminded that reading for comprehension was used by students through online resources for reading text to comprehend. The scarcity of such studies did not permit the creation of any firm conclusions or generalizations about the reading strategies and factors affecting reading comprehension. This present research examined scaffolding and metacognitive Strategies in reading comprehension of engineering students in QUEST, Pakistan.

Different studies such as Taverner (1990), Aebersold \& Field (1997), and Urquhart \& Weir (1998) described reading comprehension as the most difficult area which has not been comprehended and elaborated in terms of meaning of the text. However, reading comprehension as in the words of (Urquhart \& Weir, 1998, p. 17) means "the whole parcel of cognitive activities" that readers initiate in order to comprehend the text for apprehension the correct meaning. Similarly, Taverner (1990, p. 4) defined reading comprehension for "a means of extending experience" based on the reading material which they read and perceive the actual meaning according to the text. Aebersold \& Field (1997) described reading a way that readers undertake by involving text material and readers through interactions.

\section{Bottom-up and Top-down Reading Models}

However, bottom-up and top-down reading models describe in depth about the development of reading comprehension and reading speed if these can be followed in classroom practices. The bottom-up theory creates the fundamental aptitudes which are identified with syllables, letters, and words in content structure for starting readers. Gough (1972) has presented this theory of reading as an unraveling process for every letter basis. This implies that translation of such messages can be gotten from decoding the words included in the article to get the significance out of it. Accordingly, there is conceivable delicate to effortlessly overlook what the reader has comprehended from the content (Nuttall, 1996). Therefore, perception is attained by the student's understanding of each expression used in the content. The more natural the reader with a certain expression, the more unmistakable the entire significance of the content is to him/her. This advances familiarity with reading. Besides, comprehension is attained once the reader has deciphered the significance out of each one expression through its definition, subsequently acquiring a general thought about the article. Then again, researchers are in uncertainty of its model in spite of its validity subsequent to there is a sure intricacy included the relationship between the spelling and the sound of the expression (Chen, 2002).

However top-down theory of reading is used for handling cognitive perspective of reading by developing the part of foundation learning that is available in the printed content. Top-down reading theory underscores "from mind to content" (Eskey, 2005, p. 564) of readers who survey their reading methodology focusing around the content of the text by opposing the genuine substance of the content. The establishment of this model singularly lays on prior information of the readers which dismisses unmistakable substance related to the composed content (Smith, 2004). Chinwonno (2001) further specifies that a reader's current information would focus on his/her perception of the content. This model turns into a powerful perspective for readers, particularly when removing the forecast, setting hints, and the principle thoughts of the content by the students. This model stresses the imperativeness of having different reading materials and distinctive levels of dialect trouble that are significant to the need of the students.

\section{Related Literature}

Fisher \& Frey (2003) used gradual release model and analyzed 31 students in a first-year section in San Diego, 
California. The "genre studies" course was conducted for 90 minutes. Students were proposed to receive "genre studies" course learning. Students brainstormed ideas and discussed topics. Similarly, students' reading ability was also evaluated. Similarly, Wilkinson \& Son (2011) asserted that reading comprehension based on the text or inter-textually helps to foster the mind of students by enhancing the level of comprehension and make learners to read independently. Further, in 21st century, research is continued to understand and develop reading acquisition, skilled reading, and a plethora of models. Different theories based on psycholinguistics and metacognitions are suggested to work in for promoting research in the field (Snowling, 2002). In cognitive factors and external factors learners bring comparison based on cultural influences to the activity of reading. Cognitive factors do not develop in loneliness but coexist and interact with others in the classroom activities. Reading is a multifaceted procedure to cognize internal as well as external aspects of metacognition. Snowling (2002) investigated that early readers follow the pattern based on top-down approach in which higher level of reading is observed as the driving force for learning that depends on lower level skill including decoding. While, Stanovich (1980) rejected top-down models and favored integrated approach that explains how learners with reading difficulties can overcome weaknesses in the reading. Interactive models are based on reading include connectionist models, cognitive processing models, and parallel models (Stanovich, 1980). These models support within the reading process by developing interaction among students with that of their peers, and their teachers as well instead of following a number of stages. However, they do differ in terms of the direct or indirect routes that prevail between phonological decoding and semantic recall of words in the text. Stewart (2002) indicated that reading acquisition can be developed through sound knowledge of letter-sound relationships that can store lexical items in the mind.

Further, Snowling (2002) asserted that weak phonological coding leads to less efficient decoding and makes the basis of reading difficulties for dyslexic students. Cain, Oakhill, \& Bryant (2004) investigated that lower level skills including decoding develops comprehension strategy among children; however, this turns less effective when readers get older and experienced. These are based on making inference, integrated text into prevailing knowledge, monitoring of reading comprehension, and know-how of text formation. Reading is an expertise considered vital for accomplishment in life. It is likewise considered by Alyousef (2005) as an entryway to creating fundamental learning, in light of the fact that it is through reading, among other learning passages, that are looked into different societies and increase experiences into new fields. Further, Alyousef (2005) stated that reading is a shared practice of a reader on text that develop fluency and speed in reading with cognition. Notwithstanding the imperativeness of creating solid reading abilities, there is much confirmation recommending numerous students are experiencing issues adapting to comprehension texts (American College Testing, 2006).

Block (1986) stated that learners experience tension and inconvenience while reading on the grounds that notwithstanding other blocking variables, for example, low collection of vocabulary and deficient reading abilities. Reading comprehension tends to undertake students conflicting in terms of comprehending content. Shanahan et al. (2010) stated that strategies in reading for intellectual capacity of the text support person who reads to upgrade the level of intellectual capacity in order to overcome barriers by adjusting deficient learning identified with content. Students who use cognitive systems to adapt for comprehension difficulties get to be more inspired to read (Lapp, Fisher, \& Grant, 2008). Shanahan et al. (2010) laid out various methods to solve reading inabilities. However, Kintsch (1998) used Construction-Integration Model of Comprehension to investigate reading comprehension through metacognitive strategies in order to support students to measure the possibility of remembering the text for future to be used. Camahalan (2006) suggested that metacognitive aptitudes develop students' approach to learn new text with its comprehension in reading. Similarly, Boulware-Gooden, Carreker, Thornhill, \& Joshi (2007) stated that students using metacognitive strategies in reading can make the text appropriately when used this with certain procedures by adjusting in different forms. Kelly et al. (2001) stated that good readers and poor readers can easily be known through metacognitive strategies. Camahalan (2006) demonstrated that students do not learn techniques or abilities as promptly as do grown-up learners on the grounds that young learners have less capacity to arrange material. Metacognitive procedures have all the earmarks of being less created in young learners. Regardless, numerous abilities identified with reading comprehension stay immature even among young learners (Thiede, Griffin, Wiley, \& Redford, 2009). Block (1986) additionally called attention to that the variables that impact perusing capacity increment geometrically when managing second language reading. This research has taken the main important objective that includes: to identify what strategies first year engineering students use in developing their reading at QUEST, Pakistan.

\section{Research Methodology}

Quantitative instrument based on a set of questionnaire was used to get the perceptions of engineering students of different engineering departments and teachers of QUEST, Pakistan. However, 400 questionnaires were given to the respondents of the study and 300 students returned these questionnaires; whereas, 11 teachers gave back 
after filling the data. This survey questionnaire was partially constructed by the researcher and partially was adopted from Fauzan (2003) who already conducted research on the use of metacognition. The questionnaire was based on practice of reading comprehension using five Likert scale requiring engineering student respondents to specify their level of agreement. These respondents were asked to choose one of five different responses that included: Essential, Very necessary, Necessary, Fairly Necessary, and Unnecessary for the reading comprehension. These respondents were explained the purposes of the questionnaire and informed them to ask any question if they needed any help or guidance related to this study. These respondents were also informed that they are free if they do not wish to participate. The questionnaires were administered in the following four engineering departments of QUEST, Pakistan in the presence of the researcher.

Table 1. Using instrument and respondents from the departments

\begin{tabular}{lllll}
\hline Instruments used & Mechanical & Energy Environment & Electrical & Computer System \\
& Engineering & Engineering & Engineering & Engineering \\
& Department & Department & Department & Department \\
\hline Questionnaire & 3 teachers; & 3 teachers; & 3 teachers; & 2 teachers; \\
& 90 students & 60 students & 95 students & 55 students \\
\hline
\end{tabular}

\subsection{Ethical Considerations}

Official letters through the directorate of Planning and development were sent to the Vice Chancellor, Pro-Vice Chancellor, and the chairmen of engineering departments of QUEST, Pakistan for getting permission and gaining access to seek the participation of the respondents in order to collect data for this research. Though, there was no need to seek permission for conducting research as the researcher belonged to the QUEST to pursue higher studies, yet the researcher asked for permission. The study was started after the QUEST authority granted permission to do the research. Further, Fauzan (2003) was also requested to grant permission to use the questionnaire of her study through email. The permission was granted for using the questionnaire through email.

\section{Analysis of the Data and Research Findings}

Questionnaire data analysis was carried out using the Statistical Package for Social Sciences (SPSS) version 17. Descriptive statistics were used to analyze research variables for producing the Percentages, Mean and Standard Deviation of the data. To answer the main objective, the respondents' responses from the 311 returned questionnaires about the reading comprehension are presented in the following table based on the eighteen categories.

Table 2. Frequency of reading comprehension $(\mathrm{N}=311)$

\begin{tabular}{|c|c|c|c|c|c|c|c|}
\hline \multicolumn{8}{|c|}{ Reading Comprehension } \\
\hline & Essential & Very Necessary & Necessary & Fairly Necessary & Unnecessary & $M$ & $S D$ \\
\hline $\begin{array}{l}\text { Asking questions before, during, } \\
\text { and after reading }\end{array}$ & 67.2 & 21.5 & 6.4 & 4.8 & 0.00 & 1.4887 & .81856 \\
\hline $\begin{array}{l}\text { Considering several alternatives to } \\
\text { a problem in text }\end{array}$ & 23.2 & 54.3 & 19.3 & 1.6 & 1.6 & 2.0418 & .79607 \\
\hline $\begin{array}{l}\text { Brainstorming about the topics of } \\
\text { the text }\end{array}$ & 60.1 & 28.3 & 10.0 & 1.6 & 0.00 & 1.5305 & .73935 \\
\hline $\begin{array}{l}\text { finding the usefulness of the text } \\
\text { while reading }\end{array}$ & 31.5 & 45.0 & 20.3 & 3.2 & 0.00 & 1.9518 & .80377 \\
\hline $\begin{array}{l}\text { Developing general and technical } \\
\text { vocabulary }\end{array}$ & 53.4 & 33.4 & 13.2 & 0.00 & 0.00 & 1.5981 & .71111 \\
\hline $\begin{array}{l}\text { Reading passages/essays/textbooks } \\
\text { from easy to difficult }\end{array}$ & 31.8 & 44.1 & 19.3 & 3.2 & 1.6 & 1.9871 & .88709 \\
\hline $\begin{array}{l}\text { While taking reading class, I help } \\
\text { students to overcome barriers to } \\
\text { understanding }\end{array}$ & 33.8 & 25.4 & 32.8 & 6.4 & 1.6 & 2.1672 & 1.02123 \\
\hline Think-aloud practices & 25.7 & 37.0 & 24.4 & 9.6 & 3.2 & 2.2765 & 1.05068 \\
\hline Read aloud practices & 28.9 & 25.7 & 24.4 & 17.7 & 3.2 & 2.4051 & 1.17082 \\
\hline Rereading for deeper meaning & 53.1 & 30.2 & 13.5 & 1.6 & 1.6 & 1.6849 & .88193 \\
\hline Using text coding & 29.6 & 28.6 & 22.5 & 11.3 & 8.0 & 2.3955 & 1.24221 \\
\hline $\begin{array}{l}\text { Overcoming complexities in } \\
\text { reading reports' text }\end{array}$ & 22.2 & 40.8 & 24.1 & 8.0 & 4.8 & 2.3248 & 1.05677 \\
\hline
\end{tabular}




\begin{tabular}{|c|c|c|c|c|c|c|c|}
\hline Making concepts maps & 28.9 & 33.4 & 28.0 & 6.4 & 3.2 & 2.2154 & 1.03576 \\
\hline Making story maps & 32.2 & 30.2 & 23.2 & 11.3 & 3.2 & 2.2315 & 1.11490 \\
\hline Reading through timelines & 28.9 & 41.8 & 20.9 & 6.8 & 1.6 & 2.1029 & .95158 \\
\hline Building word walls & 38.9 & 33.8 & 24.1 & 3.2 & 0.00 & 1.9164 & .86849 \\
\hline Making mind maps & 34.7 & 31.2 & 19.3 & 10.0 & 4.8 & 2.1897 & 1.15815 \\
\hline $\begin{array}{l}\text { Understanding self- intellectual } \\
\text { strengths and weaknesses }\end{array}$ & 56.9 & 31.5 & 11.6 & 0.00 & 0.00 & 1.5466 & .69346 \\
\hline
\end{tabular}

The above table revealed the average use of the eighteen main reading categories which were reported by 311 engineering respondents. The results showed that the "essential" need to be used for reading comprehension category was asking question before, during, and after reading with $67.2 \%$ to develop reading and to clarify the exact meaning of the text. Questioning category would be beneficial for understanding the text properly followed by the brainstorming about the topics of the text having $60.1 \%$. The brainstorming category would enable readers to see the two sides of the text in order to have a wider meaning and sense of the passages. The most respondents asserted that questioning and brainstorming can be beneficial for them to develop their reading and felt dire need of these two categories to be used in reading practice. Further, the reading category including "understanding self-intellectual strengths and weaknesses" was rated by respondents as the "essential" with 56.9\% to be used in reading and comprehension in order to know the power of perception of the text and problems based on poor comprehension; hence the respondents needed "understanding self-intellectual strengths and weaknesses" to be practiced in order to develop their reading comprehension. Similarly, the respondents of this study rated "considering several alternatives to a problem in text" as very necessary with $54.3 \%$ to be used to develop reading comprehension. Moreover, the respondents of this study rated "developing general and technical vocabulary" category as the "essential" category with $53.4 \%$ to develop reading comprehension. The respondents termed this category as the "essential" because general and technical vocabulary would mainly enhance their present capability to read and develop future comprehension proficiency of the text. Similarly, the category "rereading for deeper meaning" with $53.1 \%$ was rated as the "essential" for developing reading comprehension. The "rereading" gives deeper meaning of the text and increase complete command for understanding passages by enabling readers to perceive the correct meaning with wide range of understanding of the texts.

Therefore, feeling the dire need, the respondents termed rereading category as the "essential" to understand the confused parts of the passages. The other categories of reading comprehension including "finding the usefulness of the text while reading" with $45.0 \%$, "Reading passages/essays/textbooks from easy to difficult" with $44.1 \%$, Reading through timeline's with $41.8 \%$, and "Overcoming complexities in reading reports' text" having $40.8 \%$ were grouped as "very necessary" for developing reading comprehension enhancing their reading proficiency. Conversely, the other categories including think-aloud practices, read aloud practices, using text coding, making concepts maps, making story maps, building word walls, and making mind maps were rated either as "necessary" or "fairly necessary" in promoting reading proficiency. The mean score for read aloud practices category $(M=$ 2.40) for all respondents was the highest; while the mean score for asking questions before, during, and after reading $(M=1.48)$ was the lowest. However, no category of reading comprehension fell into low level of use.

\section{Discussion, Conclusion and Contribution}

The present study investigated the eighteen important categories in the reading comprehension variable. The highest mean score was for read aloud practices category $(M=2.40)$ rated by all respondents; while the mean score for asking questions before, during, and after reading $(M=1.48)$ was the lowest. However, no category of reading comprehension fell into low level of use. The engineering respondents used metacognitive Strategies at QUEST, Pakistan and the way these respondents adopted to use in reading text. This present research indicated that the engineering students were completely attentive and knew about their reading comprehension strengths and weaknesses to regulate their thinking abilities at the time of reading texts of the passages. The results acquired from the questionnaire data suggest that the engineering respondents used their metacognitive strategies in order to make their comprehension easy to apprehend the meaning of reading passages.

The results of this present research are reliable and consistent as compared with the results of earlier studies which asserted that the readers always used metacognitive strategies to help their reading comprehension to be enhanced (Dhieb-Henia, 2003) and make students to know their reading proficiency and practice for its improvement (Li \& Munby, 1996; Ra-Ngubtook, 1993). This research has shown the significance in terms of strategies (metacognition) for engineering students in their reading practice and the processes of comprehension. These findings are regarded as the consistent with the study of Chumpavan (2000) which revealed the metacognitive strategies to be used by 
Thai students studying at Illinois State University for more than two years in USA; they were highly expert in reading comprehension. The study focused on metacognitive strategies and her findings revealed that the participants applied strategies for planning, monitoring, and evaluating their reading texts, their abilities, and their comprehension proficiency. On the contrary, this present research approves the claims made in the past research in terms of the strategies identified and used by the participants. This present study confirms that using metacognitive strategies means improve the comprehension levels of the texts by the engineering students. The respondents of this study reported that they used different metacognitive strategies in order to develop their understanding. Moreover, the results of this study also informed that they sometimes asked for help to their mentors or some times to their peers for clarifying the texts by telling and guiding about the meaning of the texts. In addition, the results of this present research are matching and seem parallel as compared with the results of the study as shown in Li \& Munby's (1996) research that reported about metacognitive strategies which are interconnected with reading contents; these strategies were not existed if there was no reading. Therefore, the strategies used by the engineering respondents in the present study can be the same with that of Li \& Munby's (1996) study in order to develop their reading and comprehension proficiency of the texts. In short, metacognitive strategies exercised greater impact on the minds of the readers to flourish their interest in reading. The results of this study would be beneficial for the students of all levels to promote their reading habits in order to comprehend the texts along with its proper meaning. The results of this study reported that the use of strategies would enable students to become self-regulatory in terms of accomplishing their reading comprehension by overcoming their reading barriers.

\subsection{Contribution of the Study}

The data collected for this study provided teachers teaching reading comprehension with information regarding the extent to which reading comprehension instruction is incorporated into first year engineering students' classrooms. Data from this study would assist teachers within the organization to address concerns regarding reading comprehension of first year engineering undergraduates. Results from this research will also provide QUEST administrators with information on the subject of the effectiveness of teachers in promoting reading comprehension. Through this research study, different theories were incorporated to support the study's purpose of examining reading comprehension. From the results in the present research, it can be observed that metacognitive strategies are useful to increase engineering students' reading proficiency. Therefore, following important recommendations are suggested as the contribution of the study.

1) Engineering students should be involved in problem-solving reading courses in order to facilitate their understanding of reading texts.

2) When students face difficulties with unknown words, their teachers should suggest them to look for the meaning from dictionary or they should help them to predict a suitable meaning before looking in the dictionary.

3) Familiarizing engineering students with the use of a number of operative strategies in reading would support them improve their cognitive processes.

4) The choice of effective metacognitive strategies would decrease their inaccuracies and errors including difficulties in reading.

5) When cognitive thinking processes are developed, readers select the metacognitive strategies that solve their reading difficulties and facilitate their understanding of texts.

\section{References}

Aebersold, J. A., \& Field, M. L. (1997). From reader to reading teacher. Cambridge: Cambridge University Press.

Alyousef, H. S. (2005). Teaching reading comprehension to ESL/EFL learners. The Reading Matrix, 5(2), 143-154.

American College Testing. (2006). Reading between the lines: What the ACT reveals about college readiness in reading. Retrieved from http://www.act.org/research/policymakers/pdf/reading_summary.pdf

Anderson, V. (1991). Training to foster active reading strategies in reading-disabled adolescents. Paper presented at the annual meeting of the American Educational Research Association, Chicago.

Block, E. (1986). The comprehension strategies of second language readers. TESOL Quarterly, 20(3), 463-494. https://doi.org/10.2307/3586295

Boulware-Gooden, R., Carreker, S., Thornhill, A., \& Joshi, R. (2007). Instruction of metacognitive strategies enhances reading comprehension and vocabulary achievement of third-grade students. Reading Teacher, 61(1), 70-77. https://doi.org/10.1598/RT.61.1.7 
Cain, K., Oakhill, J., \& Bryant, P. (2004). Children's reading comprehension ability: concurrent prediction by working memory, verbal ability, and component skills. Journal of Educational Psychology, 96, 31-42. http://dx.doi.org/10.1037/0022-0663.96.1.31

Camahalan, F. M. G. (2006). Effects of a metacognitive reading program on the reading achievement and metacognitive strategies of students with cases of dyslexia. Reading Improvement, 43(1), 77-93.

Chen, H. C. (2002). A preliminary study of Chinese EFL learners' difficulties invocabulary learning and remedial learning strategies. Papers selected from the 17th conference of TVES Education, 81-91, Taipei: Crane.

Chinwonno, A. (2001). A comparison of Thai and English reading comprehension strategies of pre-service teachers in Thailand. $\mathrm{PhD}$ dissertation, Ohio University.

Chumpavan, S. (2000). A qualitative investigation of metacognitive strategies used by Thai students in second language academic reading. SLLT, 9, 62-77.

Cohen, A. D. (1998). Strategies in learning and using a second language. NY: Addison Wesley Longman.

Dhieb-Henia, N. (2003). Evaluating the effectiveness of metacognitive strategy training for reading research articles in an ESP context. English for Specific Purposes, 22, 387-417. https://doi.org/10.1016/S0889-4906(03)00017-6

Eskey, D. E. (2005). Reading in a second language. In E. Hinkel (Ed.), Handbook of Research in second language teaching and learning (pp. 563-580). Mahwah, NJ: Lawrence Erlbaum.

Fauzan, N. (2003). The effects of metacognitive strategies on reading comprehension: a quantitative synthesis and the empirical investigation. Durham theses, Durham University. Retrieved from http://etheses.dur.ac.uk/1086/

Fisher, D., \& Frey, N. (2003).Writing instruction for struggling adolescent readers: A gradual release model. Journal of Adolescent and Adult Literacy, 46, 396-405.

Flemming, L. E. (1997). Reading for thinking (2nd ed.). Boston: Houghton Mifflin.

Gough, P. B. (1972). One second of reading. In J. F. Kavanagh \& I. G. Mattingly (Eds.), Language by ear and by eye (pp. 331-358). Cambridge, MA: MIT Press.

Hammadou, J. (1991). Interrelationship among prior knowledge, inference, and language proficiency in foreign language reading. The Modern Language Journal, 75(1), 27-38. https://doi.org/10.1111/j.1540-4781.1991.tb01080.x

Kelly, M., Moore, D. W., \& Tuck, B. F. (1994). Reciprocal teaching in a regular primary classroom. The Journal of Educational Research, 88(1), 53-61. https://doi.org/10.1080/00220671.1994.9944834

Lapp, D., Fisher, D., \& Grant, M. (2008). You can read this text-I'll show you how: Interactive comprehension instruction. Journal of Adolescent \& Adult Literacy, 51(5), 372-383. https://doi.org/10.1598/JAAL.51.5.1

Leddy C. (2008). The Alarming state of reading in America. Writer, 121(5).

Levitov, D.D. (2010). Reading as a 21 st-century skill cannot be taken lightly, School Library.

Li, S., \& Munby, H. (1996). Metacognitive strategies in second language academic reading: A qualitative $\begin{array}{llll}\text { investigation. English for } & \text { Specific }\end{array}$ https://doi.org/10.1016/0889-4906(96)00004-X

Nuttall, C. (1996). Teaching reading skills in a foreign language (New edition). Oxford, UK: Heinemann.

Ra-Ngubtook, W. (1993). A comparison of the effectiveness of "direct" and "embedded" metacognitive learning strategy training models in English reading comprehension for upper secondary school students. Unpublished Master's thesis, Chulalongkorn University, Bangkok, Thailand.

Shanahan, T., Callison, K., Carriere, C., Duke, N. K., Pearson, P. D., Schatschneider, C., \& Torgesen, J. (2010). Improving reading comprehension in kindergarten through 3rd grade: A practice guide. Washington, DC: National Center for Education Evaluation and Regional Assistance, Institute of Education Sciences, US Department of Education. $\quad$ Retrieved from http://ies.ed.gov/ncee/wwc/pdf/practice_guides/readingcomp_pg_092810.pdf

Smith, F. (2004). Understanding reading: A psycholinguistic analysis of reading and learning (6th ed.). Mahwah, NJ: Lawrence Erlbaum. 
Snowling, M. (2002). Dyslexia: Individual and developmental differences, Learning and Teaching Reading. British Journal of Educational Psychology, Monograph Series II, the British Psychological Society.

Stanovich, K. E. (1980). Toward an interactive-compensatory model of individual differences in the development of reading fluency. Reading Research Quarterly, 16, 32-71. https://doi.org/10.2307/747348

Stewart M. T. (2002). Best practice: Insights on literacy instruction from an elementary classroom. Newark, DE: International Reading Association; Chicago: National Reading Conference.

Taverner, D. (1990). Reading within and beyond the classroom. Milton Keynes, Philadelphia: Open University Press.

Thiede, K. W., Griffin, T. D., Wiley, J., \& Redford, J. S. (2009). Metacognitive monitoring during and after reading. In D. J. Hacker, J. Dunlosky, \& A. C. Graesser (Eds.), Handbook of Metacognition and Self-Regulated Learning (pp. 85-106). New York: Rutledge.

Urquhart, A. H., \& Weir, C. J. (1998). Reading in a second language: Process product and practice. New York: Addison Wesley Longman.

Wilkinson, I. A. G. \& Son, E. H. (2011). A dialogic turn in research on learning and teaching to comprehend. In M. L. Kamil, P. B. Rosenthal, P. D. Pearson, \& R. Barr (Eds.), Handbook of reading research: Volume IV (pp. 359-387). New York: Rutledge.

\section{Copyrights}

Copyright for this article is retained by the author(s), with first publication rights granted to the journal.

This is an open-access article distributed under the terms and conditions of the Creative Commons Attribution license (http://creativecommons.org/licenses/by/4.0/). 